была посвящена актуальной проблеме гендера, причём рассматривалась как лингвистическая, так и социокультурологическая сторона вопроса. Особую дискуссию вызвала проблематика гендера в постлитературе с выходом на актуальные проблемы современности, а также вопрос гендерных ролей в культуре Трёхречья (Китай).

На конференции царила доброжелательная творческая и рабочая атмосфера, мотивирующая к установлению новых контактов с коллегами и обмену опытом. Все участники конференции получили уже изданный сборник тезисов конференции, статьи на тему доклада можно опубликовать в рецензируемом научном журнале Rossica Olomucensia.

Полина Золина, Ольга Бергер

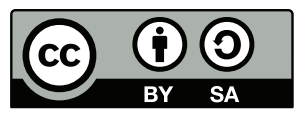

This work can be used in accordance with the Creative Commons BY-SA 4.0 International license terms and conditions (<https://creativecommons.org/licenses/by-sa/4.0/legalcode>). This does not apply to works or elements (such as images or photographs) that are used in the work under a contractual license or exception or limitation to relevant rights.

\title{
Студенческие диалоги о Восточной Европе (Брно-Оломоуц-Прага)
}

18 октября 2019 года на философском факультете Карлова университета состоялась первая научно-студенческая конференция, посвященная Восточной Европе. На конференции встретились студенты и выпускники магистратуры и докторантуры трех чешских университетов (Университет им. Масарика в Брно, Университет им. Палацкого в Оломоуце, Карлов университет в Праге) и представили результаты своих исследований. Конференция ставит перед собой сразу несколько задач: развить и укрепить преемственность славистических традиций, дать возможность молодым исследователям завязать новые контакты и презентовать свои научные работы, вдохновить ученых на междисциплинарное сотрудничество.

Выступления на конференции была разделены тематически: сначала прозвучали доклады на культурно-исторические темы, далее участники ознакомились с докладами лингвистической проблематики, закрывала работу конференции самая многочисленная по количеству докладов литературоведческая секция. 
Планируется, что конференция станет традиционной, местами проведения конференции в следующие годы должны стать философские факультеты Университета им. Палацкого и Университета им. Масарика.

Ольга Бергер

This work can be used in accordance with the Creative Commons BY-SA 4.0 International license terms and conditions (<https://creativecommons.org/licenses/by-sa/4.0/legalcode>). This does not apply to works or elements (such as images or photographs) that are used in the work under a contractual license or exception or limitation to relevant rights. 
